\title{
Totalitaryzm a funkcjonalistyczna utopia. Wątki systemowe w twórczości Janusza A. Zajdla
}

Fantastyka zaangażowana społecznie ma w Polsce silne, choć częściowo zapomniane tradycje. Fantastyka jako literatura spekulatywna i mogąca bezpiecznie oderwać się od rzeczywistości często bowiem bywa bezpieczną trybuną do wygłaszania zarówno kontrowersyjnych komentarzy społecznych, jak i mniej lub bardziej szalonych wizji przyszłego bądź przeszłego życia społecznego. Z powodu zwykle rozrywkowego charakteru jej dorobek jako właśnie literatury spekulatywnej jest jednak często ignorowany i pomijany przez główny nurt krytyki społeczeństwa, będącej istotnym składnikiem literatury głównego nurtu.

Fantastyka socjologiczna ${ }^{1}$ charakteryzuje się przeniesieniem punktu ciężkości fabularnej z szeroko rozumianej fantastyczności - lub traktowanie jej instrumentalnie - na społeczeństwo, które znajduje się w centrum, a nie na marginesie przedstawionego świata. Opis wizji społeczeństwa oraz zachodzących w nim zmian jest z punktu widzenia utworu ważniejszy od — czasami wręcz pretekstualnej — fabuły. Początki tak rozumianej fantastyki socjologicznej (lub po prostu społecznej) sięgają nurtu utopijno-dystopijnego w piśmiennictwie politycznym. W niektórych przypadkach trudno jednak wyznaczyć konkretne granice piśmiennictwa politycznego i społecznego, zwłaszcza w sytuacji, w której pod płaszczem literatury fantastycznej, a więc z gruntu niepoważnej i rozrywkowej, można było ukryć radykalne poglądy i projekty bez ryzyka politycznej kompromitacji ${ }^{2}$.

1 Pozwalam sobie na wprowadzenie roboczego rozróżnienia fantastyki socjologicznej — skupiającej się na krytyce bądź projektach społecznych — od fantastyki socjologizującej, która traktuje wątki społeczne w sposób powierzchowny, jedynie jako dekoracje, w których osadza fabułę. Wyraźnie odróżniam ją też od fantastyki obyczajowej, często socjologizującej, ale w której oś fabularna jest nadrzędna wobec opisu struktur społecznych.

2 Znany polityk i prawnik, Roman Giertych, swoje idee programowe na temat członkostwa Polski w Unii Europejskiej wyraził w dystopijnej powieści fantastycznej Za błękitna kurtyna, wydanej jednak pod pseudonimem. 
W niniejszym tekście posługuję się dwoma wstępnymi założeniami, które stają się podstawą analizy tekstów poddanych badaniu.

Po pierwsze, definiuję fantastykę socjologiczną jako gatunek, który zajmuje się opisem fikcyjnych społeczeństw, w tym przewidywaniem przyszłych zjawisk i struktur społecznych, często zawierający alarmistyczne w tonie ostrzeżenia przed zagrożeniami czyhającymi w przyszłości na ludzkość, krytykę zjawisk współczesnych oraz przedstawianie programów i projektów zmian społecznych. Analizując twórczość Janusza A. Zajdla, będę się obracać w kategorii fantastyki socjologicznej sensu stricto, w pełni spełniającej warunki tak sformułowanej definicji.

Po drugie, odrzucam często prawdziwe, lecz nie uniwersalne dla polskiej fantastyki socjologicznej, domyślne utożsamienie socjologiczności z politycznością. Dla twórczości Zajdla przyjęcie takiego założenia skazuje bowiem badacza na ograniczenie się do najbardziej powierzchownej warstwy treści, bardzo silnie związanej z uwarunkowaniami tu i teraz okresu ich powstawania, ale odbierającej przez to twórczości Zajdla uniwersalny wymiar. Dlatego mimo pokusy i powszechnego przyjmowania takiego założenia $\mathrm{w}$ wypadku powieści omawianego tu autora dotyczących futurologicznej analizy społeczeństw przyszłości odrzucam je z całą stanowczością ${ }^{3}$ W dalszej części tekstu przytaczam kilka definicji totalitaryzmu jako systemu rządów politycznych, by wykazać, że centralną osią spinająca twórczość Zajdla nie jest totalitaryzm, a raczej nowatorskie podejście do konstruowania utopii społecznych opartych na funkcjonalistycznym strukturalizmie.

Za ojca współczesnej fantastyki naukowej uważa się Herberta George’a Well$\mathrm{sa}^{4}$, to on także jako pierwszy autor powieści spekulatywnych podjął problematykę społeczną — Wehikut czasu (1895) oraz Kiedy śpiacy budzi się (1899) uznawane są za pierwsze dzieła fantastyki socjologicznej sensu stricto. Najważniejsze dzieła tego gatunku powstały jednak w XX wieku — chodzi tu o takiej powieści, jak Nowy wspaniały świat Huxleya (1932), Folwark zwierzęcy (1945) i 1984 (1949) Orwella oraz Fahrenheit 451 (1953) Raya Bradbury'ego. Tylko jedna z nich powstała przed II wojną światową, która miała ogromny wpływ na twórców literatury spekulatywnej o społecznych zainteresowaniach i w mniejszym

3 M. Parowski, Z pozycji matego brata, „Nowa Fantastyka” 1990, nr 2, s. 58-59; A. Podlewski, My z niego wszyscy? Fantastyka socjologiczna w roku zajdlowskim, „Teologia Polityczna” 2013, nr 2, s. 81; E. Wnuk-Lipiński, Science fiction jako opis socjologiczny, „Newsweek” 11.12.2004, http://www.newsweek.pl/science-fiction-jako-opis-socjologiczny,45744,1,1.html (dostęp: 1.05.2016).

${ }^{4}$ Mimo wcześniejszych prac filozoficznych o charakterze utopijnym za ojca „utopii” i twórcę terminu uznaje się Thomasa More'a. Od publikacji jego dzieła wielu autorów (jak Tommaso Campanella, Francis Bacon, Charles Fourier czy Jonathan Swift) zadało sobie trud opisu państwa doskonałego, najczęściej stanowiącego podstawę moralitetów o podłożu politycznym. Z kolei za twórcę nowożytnej dystopii uznaje się Johna Miltona z jego Rajem utraconym; pierwsze odnotowane użycie terminu dystopia rejestrujemy w 1868 roku podczas parlamentarnego przemówienia Johna Stuarta Milla, ale jego popularyzację notuje się wraz z początkami literatury fantastycznej (Jules Verne, Herbert George Wells). 
lub większym stopniu zapładniała ich twórczo przez kilka kolejnych dziesięcioleci ${ }^{5}$. Wszystkie jednak są odpowiedzią na rzeczywistość współczesną autorom, niezależnie od tego, czy jest nią zagrożenie ze strony Związku Radzieckiego, rewolucja, faszyzm czy maccartyzm. Fantastyka socjologiczna najczęściej jest odpowiedzią na konkretne zjawiska społeczne — próbuje przedstawić ich zazwyczaj negatywne skutki, metody ich przezwyciężenia, możliwe reakcje ludzkie oraz dostępne refleksjom autora alternatywy.

W tym świetle tradycyjna fantastyka socjologiczna w Polsce ma swój specyficzny i wyjątkowy charakter6 ${ }^{6}$. Literatura w krajach bloku wschodniego była bowiem bardzo kontrolowana przez państwo. Swoboda literacka istniała tylko do momentu, w którym literatura dotykała problemów politycznych lub próbowała w jakikolwiek sposób krytykować państwo lub mocarstwo zaprzyjaźnione. W takiej sytuacji nie dziwi, że problematykę społeczną podejmowali jedynie nieliczni autorzy, którzy w dodatku najczęściej ograniczali się do apologetycznych opisów socjalistycznych rajów przyszłości?

W Polsce schemat ten jako pierwszy przełamał Stanisław Lem swoimi antyutopijnymi Bajkami robotów (1964), jednak miały one charakter ogólnoludzkich filozoficznych przypowieści. Zupełnie oderwane od tu i teraz autora oraz czytelników, w swej wielopłaszczyznowej strukturze mogą być traktowane w warstwie fabularnej również jako krytyka kapitalizmu, co niewątpliwie ułatwiło Lemowi ich publikacje. Ponadczasowy charakter i mnogość interpretacyjna na długo zapewniły im także miejsce w kanonie lektur szkolnych.

Podgatunek literacki określany jako polska fantastyka socjologiczna zaczął się wyłaniać w latach siedemdziesiątych. W 1973 roku Adam Wiśniewski-Snerg opublikował swoją powieść Robot (1973), dając początek odrębności polskiej szkoły fantastyki socjologicznej, która dominowała w polskiej fantastyce przez całe lata osiemdziesiąte, praktycznie marginalizując wszystkie inne nurty fantastyczne, aż do debiutu Andrzeja Sapkowskiego w 1986 roku.

Polska fantastyka socjologiczna dość wyraźnie dzieli się pod względem podejmowanej problematyki na trzy okresy — określiłem je roboczo okresem analitycznym, reakcyjnym oraz przyszłościowym. Pierwszy z nich - wywodzący się z tradycyjnej fantastyki socjologicznej definiowanej jako literatura opisująca

5 Wpływ wojny da się odnaleźć w twórczości wielu pisarzy, takich jak na przykład Robert Heinlein, Isaac Assimov, Kurt Vonnegut, John Wyndham, Richard Matheson, Anthony Burgess, Philip K. Dick, Harlan Ellison.

${ }^{6}$ Pewne elementy zbliżonego podejścia dają się zauważyć u pisarzy zza całej żelaznej kurtyny, jednak tylko w Polsce fantastyka socjologiczna stała się dominującą forma pisarstwa fantastycznego lat osiemdziesiątych.

7 Ten flirt z systemem nie ominął nawet największych gwiazd fantastyki bloku wschodniego: Stanisława Lema (Astronauci z 1951; Obłok Magellana z 1954), Kira Bułyczowa (cykl guślarski) czy wczesnych utworów Arkadija i Borisa Strugackich; ani twórców fantastyki młodzieżowej, takich jak Bohdan Petecki (na przykład X1 uwolnij gwiazdy z 1977). 
totalitaryzm $^{8}$ (między innymi Zajdel, Edmund Wnuk-Lipiński, Wiśniewski-Snerg, Andrzej Wójcik i Andrzej Krzepkowski, Maciej Parowski, Marek Oramus), reakcyjny - obejmujący reakcję myślową na przełom z 1989 roku (na przykład Rafał A. Ziemkiewicz, Jacek Piekara) oraz wybiegający w przyszłość przedstawiający nowe trendy w fantastyce opartej na myśli społecznej (najbardziej znaczący przedstawiciele to Jacek Dukaj — debiut w 1990 roku i Marek Huberath - debiut w 1991). Co ciekawe, autorzy okresu pierwszego w większości zamilkli (uwaga ta dotyczy autorów nadal żyjących po 1989 roku) i nie pojawiają się w drugim okresie, gwiazdy zaś drugiego okresu w większości, mimo podejmowanych prób, nie odnajdują się w okresie trzecim jako pisarze SF.

Dla etapu, który określam jako analityczny (a który skupia się niemal w całości na antyutopijnym opisie systemów totalitarnych), najbardziej charakterystyczna, a zarazem najbardziej znana jest twórczość Janusza A. Zajdla. Problematyki totalitaryzmu dotykają $\mathrm{w}$ mniejszym bądź większym stopniu wszystkie najważniejsze utwory tego autora ${ }^{9}$. W większości ze struktur społecznych, które odgrywają centralną rolę w jego powieściach, występują te same, bardzo wyraźnie zarysowane elementy składowe. Wydaje się wręcz, że bohaterowie i akcja są pretekstualnym dodatkiem do poglądów autora na temat struktury i kształtu społeczeństwa.

Tak jak większość autorów tego okresu Zajdel traktował fantastykę socjologiczną jako substytut fantastyki politycznej, której pisanie było w systemie cenzury zabronione. Jak twierdzi Maciej Parowski ${ }^{10}$, Zajdel pracował według zarysowanego planu - jego ideé fixe było ukazanie całości systemu totalitarnego takim, jakim go doświadczał w Polsce lat siedemdziesiątych i osiemdziesiątych. $\mathrm{W}$ istniejących realiach, by umknąć cenzurze, postanowił rozbić opis rzeczywistości na elementy składowe i w poszczególnych powieściach skupiać się tylko na jednym, konkretnym, odrywając go od rzeczywistości i osadzając w wyimaginowanym świecie przyszłości.

Problemem centralnym Catej prawdy o planecie Ksi jest nieprawomocne przejmowanie władzy za pomocą kłamstwa i przemocy. Głównym tematem $\mathrm{Pa}$ radyzji jest okłamywanie społeczeństwa i konstruowanie dychotomicznego podziału na „my” i „oni” oraz budowanie wspólnoty na strachu przed wytworzonym przez propagandę wyimaginowanym zewnętrznym wrogu. Limes inferior ukazuje niedoskonałość i wewnętrzne tryby nienaturalnych i narzuconych zewnętrznie

8 E. Wnuk-Lipiński, op. cit.

9 J.A. Zajdel, Cylinder van Troffa, Warszawa 1980; idem, Limes inferior, Warszawa 1982; idem, Wyjście z cienia, Warszawa 1983; idem, Cała prawda o planecie Ksi, Warszawa 1983; idem, Paradyzja, Warszawa 1984.

10 Wydawca i przyjaciel Zajdla oraz jeden z najbardziej opiniotwórczych krytyków literatury fantastycznej. Tezę tę przytoczył w trakcie swojego wystąpienia na dyskusji panelowej: Prawem czy lewem? Czy fantastyka kocha politykę? Czy polityka inspiruję fantastykę?, która miała miejsce 30 sierpnia 2008 roku na Polconie w Zielonej Górze. 
systemów społecznych. Z kolei w Niedokończonych szkicach powieści ${ }^{11}$ miał zamiar opisać eksperymentowanie społeczne na ludziach zamkniętych w odizolowanej społeczności oraz zagrożenia tożsamości wynikające z infiltracji społeczeństwa przez wrogie jednostki nieodróżnialne od jego członków.

Powstanie powieści Zajdla jest mocno umotywowane i legitymizowane bieżącymi wydarzeniami i zjawiskami społecznymi Polski przełomu lat siedemdziesiątych i osiemdziesiątych. Książki te są skonstruowane w taki sposób,

że właściwie opowiadają one o jednostkach, ale odwołują się do milczącej wiedzy Polaków i traktują o opresji społecznej. I jako takie są przez czytelników, oraz przez przetrzymujących zrazu te teksty wydawców i cenzorów, odbierane ${ }^{12}$.

Mimo umieszczenia akcji w światach będących fantastycznymi konstruktami budowanymi skrycie z otaczającej rzeczywistości w każdej z powieści znajdują się czytelne dla mieszkańca PRL kody, których odczytanie ustawia go w odpowiedniej perspektywie poznawczej i umożliwia zrozumienie ich na głębszym poziomie. Obojętne, czy jest to specyficzne donosicielstwo Paradyzji, czy profesja Sneera z Limes inferior, będąca odpowiednikiem powszechnego wtedy cinkciarza.

Ramowe przygotowanie, wspólnota elementów kreacji pozostających rdzeniem wszystkich powieści i prostota fabuł Zajdla sprawiają, że łatwiej zapamiętywane są elementy funkcjonowania nieraz bardzo skomplikowanych systemów, które autor opisuje, niż perypetie bohaterów czy nawet sami bohaterowie. $Z$ tego wynika pierwsza wątpliwość określania powieści Zajdla jako opisujących bądź krytykujących totalitaryzm. Jest to uproszenie prawdziwe w stosunku do większości jego twórczych rówieśników, jednak wobec Zajdla krzywdzące. Totalitarne elementy wykreowanych przez niego systemów są stosunkowo słabo zdefiniowane lub wyłamują się z tradycyjnych definicji totalitaryzmu. To, na co Zajdel kładzie nacisk, czyli wewnętrzne funkcjonowanie systemów społecznych, ma jeden zespół zasad niezależnie od tego, jakie są polityczne realia systemu. Ramy interpretacyjne Zajdla można by równie skutecznie przyłożyć zarówno do systemów demokracji reprezentatywnej czy plemiennej, jak i do realiów PRL, w których powstały. Definiowanie totalitaryzmu jako takiego jest tematem znacznie wykraczającym poza ramy niniejszych rozważań, jednak by wskazać, że żadne ze społeczeństw Zajdla nie jest w istocie systemem totalitarnym w tradycyjnym rozumieniu tego zjawiska, posłużę się arbitralnie dobranym szeregiem definicji; przy czym definicje dobrałem z klucza kładącego większy nacisk na zagadnienia społeczne niż prawne funkcjonowania państwa totalitarnego, a jako mechanizm doboru posłużył mi wątek oceny PRL jako państwa totalitarnego, na czym przecież musi zasadzać się opinia o totalitarnym charakterze jego krytyki przez fantastykę socjologiczną Zajdla. Dla zachowania pewnej równowagi przytaczam

11 J.A. Zajdel, Szkice niepublikowanych powieści „Enklawa” $i$ „,Residuum”, „Nowa Fantastyka" 1986, nr 2, s. 45.

12 M. Parowski, op. cit., s. 58. 
klasyczne fragmenty definicji totalitaryzmu Hannah Arendt, Zbigniewa Brzezińskiego oraz bardzo nietypową i czysto socjologiczną, lecz mieszczącą się w nurcie opisu PRL definicję Hanny Świdy-Ziemby.

Nie istnieje wśród teoretyków i badaczy zgoda co do tego, że PRL, czyli rzeczywistość, wobec której i w opozycji do której powstawały wszystkie dzieła polskiej fantastyki socjologicznej, była systemem totalitarnym. Jacek Kurczewski już w 1981 roku odrzucał nazywanie PRL państwem totalitarnym:

Totalitaryzm zakłada bowiem skuteczne objęcie przez władzę państwową kontrolą całokształtu życia obywateli, zamienionych z powrotem w poddanych. [...] Dążenie do totalitaryzmu W systemie gospodarki upaństwowionej sprawia, że jakiekolwiek funkcjonowanie tej gospodarki musi zaprzeczyć totalitaryzmowi. Staje się on pozorny [...]. Dyrektorzy robią swoje, chomikują, fałszują sprawozdawczość, a ich nieefektywność ekonomiczna wynika nie z tego, że nie słuchają poleceń $\mathrm{z}$ góry, tylko $\mathrm{z}$ tego, że nieposłuszeństwo dokonuje się $\mathrm{w}$ ramach sztucznego systemu ekonomicznego, stworzonego przez partię $e^{13}$.

Dla twórczości Zajdla znacznie bardziej charakterystyczne jest zainteresowanie właśnie tymi dysfunkcjonalnymi elementami, które Kurczewski wskazuje jako przykład działań i związków uniemożliwiających wywieranie totalitarnej kontroli. Owe związki i relacje, tak charakterystyczne dla późnego PRL, Adam Podgórecki określa mianem „,brudnych ws pólnot”14 — to zjawiska wywierania kontroli nad określonymi środkami i zasobami dostępnymi w ramach systemu

do realizacji nie tych celów, które zostały im wyznaczone przez te systemy społeczno-polityczne, w ramach których egzystują, ale przez grupy społeczne lub jednostki używające ich dla celów autonomicznie przez siebie zdefiniowanych ${ }^{15}$.

Lifterzy i downerzy (przedstawiciele profesji działających w półświatku w ramach brudnej wspólnoty, nielegalnie pomagający zaspokoić pewne cele innym członkom społeczeństwa), o których wielu słyszało plotki, nie są dla Zajdla jedynie wentylem bezpieczeństwa, ale endemicznym dla systemu regulatorem struktury społecznej. Nie ma dla nich miejsca w ramach państwa totalitarnego, które jest w stanie i zdecyduje się rozciągnąc nad swymi obywatelami pełną kontrolę. Zajdel wydaje się zafascynowany zjawiskiem strukturalnej dysfunkcjonalności PRL i przenosi do wszystkich swoich światów elementy brudnych wspólnot. System kontrolny, mimo świadomości istnienia owych luk, nie jest zainteresowany ich eliminacją, ograniczając się do sprawowania kontroli pozornej (zarówno handel punktami, prostytucja punktowa czy zmiany kategorii społecznych w Limes inferior, specyficzny nawyk chodzenia tyłem w Paradyzji, jak i nieskuteczne ukrywanie wiedzy biologicznej w Wyjściu z cienia mogłoby zostać z łatwością wyeliminowane

13 J. Kurczewski, Dawny ustrój i rewolucja, [w:] Konflikt i solidarność, Warszawa 1981, s. 23.

14 A. Podgórecki, Kontrola społeczna trzeciego stopnia, [w:] Problemy profilaktyki społecznej i resocjalizacji, [red. H. Dziewanowska], Warszawa 1976, s. 16-17.

15 Ibidem, s. 23. 
przez system roztaczający totalitarną kontrolę). Systemy społeczne Zajdla mimo powszechności i instytucjonalnego utrwalenia tych mechanizmów - a może dzięki owym mechanizmom, co postaram się wykazać w dalszej części artykułu w przeciwieństwie do PRL mogą utrzymać się w stanie równowagi.

Znacznie bliżej światom Zajdla do spełnienia definicji akademickiej przytoczonej przez Krystynę Chojnicką i Henryka Olszewskiego:

Termin totalitaryzm [...]. W tym przypadku chodzi o całkowitą likwidację wszelkich form samodzielności społeczeństwa i poddanie ich całkowitej władzy państwa. Żadna sfera życia społecznego, łącznie z życiem prywatnym, rodzinnym $\mathrm{i}$ intymnym, nie jest wolna od ingerencji państwa ${ }^{16}$.

Jednak ponownie w żadnej z powieści Zajdla owa kontrola państwa nie jest skuteczna, a często nawet nie jest postulowana (lub jest głęboko ukryta i nierealizowana). Biorąc pod uwagę konstruowane jako centralne elementy powieści brudne wspólnoty służące obchodzeniu oficjalnych ram systemu, a najczęściej będące wręcz niezbędnymi do jego funkcjonowania zasobami kapitału społecznego, możemy uznać, że również w wypadku tak ogólnej definicji totalitaryzm nie był da Zajdla szczególnie interesujący. Oczywiście autor zauważa jego elementy i odnajdujemy je w jego powieściach, ale — wbrew pierwotnej intuicji i najbardziej rozpowszechnionemu poglądowi — w funkcjach jedynie pomocniczych.

Podobne do formułowanych przez Kurczewskiego zarzuty wobec określania PRL jako systemu totalitarnego padają w wielkiej debacie na temat ustroju Polski Ludowej już po upadku rządów komunistycznych. Andrzej Walicki posłużył się reprezentatywną dla niej następującą definicją systemu totalitarnego:

Nie można wyeliminować z pojęcia totalitaryzmu ideologicznej ofensywności i rewolucyjnego dynamizmu. W przeciwieństwie do zwykłego autorytaryzmu reżimy totalitarne [...] nie zadowalają się biernym posłuszeństwem, mobilizują masy do poparcia czynnego, do powszechnej, entuzjastycznej w formie partycypacji. Reżim totalitarny realizuje ideał konformizmu absolutnego, nie zewnętrznego tylko, lecz również wewnętrznego i nie biernego tylko, lecz aktywnego. Czyni to przy pomocy nieustannej i wszechogarniającej zorganizowanej presji moralno-politycznej, wspomaganej terrorem, ale opartej głównie na indoktrynacji, na zdolności wytwarzania stanu masowej hipnozy ${ }^{17}$.

Z pewną ofensywnością i rewolucyjnym dynamizmem mamy do czynienia w wypadku Paradyzji i Cylindra van Troffa, jednak występowania w nich będącego warunkiem totalizmu systemu czynnego zaangażowania mas już nie stwierdzimy. Sam terror systemów społecznych Zajdla jest umiarkowany i posługuje się, poza nielicznymi wyjątkami, raczej stopniowalnością potencjału konsumpcyjnego niż groźbą fizycznej przemocy. Co więcej, wątek ideologii jako takiej nie jest cechą immanentną systemów politycznych wykreowanych przez Janusza

16 K. Chojnicka, H. Olszewski, Historia doktryn politycznych i prawnych, Poznań 2004, s. 348.

17 A. Walicki, Totalitaryzm i posttotalitaryzm. Próba definicji, [w:] Spoleczeństwa posttotalitarne. Kierunki przemian, red. Z. Sadowski, Warszawa 1991, s. 20-21. 
Zajdla, najczęściej ma on charakter instrumentalny lub nawet czysto pretekstualny. W Argolandzie (Limes inferior) ideologia w świadomości społecznej jest w zasadzie zupełnie nieobecna. W pozostałych przypadkach częściej stanowi ona zasłonę skrywającą wielkie kłamstwo rzeczywistości (Cała prawda o planecie Ksi i Paradyzja) niż jest spoiwem określającym i narzucającym ramy systemu władzy. Wydaje się raczej nadbudową niż bazą i zarówno struktura fabularna, jak i wewnętrzna logika książek mogłyby się bez niej obyć.

Drugi z elementów przytaczany przez Walickiego jako „zbiorowa hipnoza” jest najważniejszy w definicji konstruowanej przez socjologa Edmunda Wnuka-Lipińskiego (który w początkach swej kariery akademickiej zasłynął cyklem powieści z gatunku fantastyki socjologicznej):

\begin{abstract}
autorów fantastyki socjologicznej nurtowało inne podstawowe pytanie: czy możliwy do wyobrażenia jest system doskonale totalitarny. Taka organizacja życia społecznego, w której życie prywatne już nie istnieje, a System kontroluje nie tylko nasze zachowania w przestrzeni publicznej, ale także nasz język komunikacji i w końcu sposób myślenia. Bowiem system doskonale totalitarny oznacza nie tyle nawet zniewolenie człowieka wbrew jego woli, ale takie przekształcenie jego świadomości, percepcji otaczającego świata i jego interpretacji, a także języka komunikacji z innymi ludźmi, by zniewolenie zniknęło z pola widzenia człowieka ${ }^{18}$.
\end{abstract}

Tworzenie totalitaryzmu doskonałego nie było celem twórczych wizji Zajdla. Jednak idea samoorganizującego się i samozarządzającego systemu, który byłby niewidoczny dla użytkowników, a jednocześnie utrzymywał ich cały czas w swych objęciach, znajdowały się w centrum jego spekulatywnych zainteresowań. Ponownie jednak analogia jego twórczości z tak definiowanym totalitaryzmem jest jedynie powierzchowna i występuje wyłącznie w Limes inferior (do czego powrócę w dalszej części pracy), albowiem jest to powieść najgłębiej zanurzona w nurcie strukturalizmu funkcjonalnego (w jej wypadku chodzi o stan homeostazy systemu), który choć niewątpliwie mógł być totalitarnie narzucony, to samo zjawisko totalitaryzacji znajduje się zupełnie poza zainteresowaniem autora i jest tylko zasugerowane jako zewnętrzna interwencja. W większości pozostałych światów Zajdla język ma więcej właściwości subwersywnych niż oficjalnych i służy do obchodzenia oficjalnych ram systemu, jednak w żadnym przypadku nie znajduje się w centrum przedmiotu zainteresowań autora, a obecne w nich jednostki doskonale zdają sobie sprawę ze swojego zniewolenia (niezależnie od tego, czy akceptują właściwą jego formę jako zniewolenie).

Również klasyczna definicja totalitaryzmu Hannah Arendt, stworzona do opisania systemów totalitarnych hitlerowskich Niemiec i stalinowskiego ZSRR, nie wydaje się skuteczna w opisywaniu systemów społecznych Zajdla:

Niezależnie od specyficznych tradycji narodowych albo szczególnych duchowych źródeł swojej ideologii, totalitarny rząd zawsze przekształcał klasy w masy, zastępował system partyjny

\footnotetext{
18 E. Wnuk-Lipiński, op. cit.
} 
nie jednopartyjną dyktaturą, lecz masowym ruchem, przesuwał centrum władzy z wojska ku policji i obierał politykę zagraniczną dążącą otwarcie do władzy nad światem ${ }^{19}$.

Definicja ta zawiera bowiem zarówno komponenty ideologiczny i aktywizacji mas, które już wskazałem jako nieobecne lub o mniejszym znaczeniu do twórczości autora Paradyzji, jak i stawia nacisk na dążenie do władzy nad światem i podporządkowanie jej polityki zagranicznej. W wypadku żadnego ze światów Zajdla nie mamy do czynienia z tak prowadzoną polityką. Komunikacja państwowa jest skierowana do wewnątrz opisywanych systemów lub w ogóle nie występuje. Systemy bowiem, jak wspomniałem, są zamknięte wewnętrznie, samoreferencyjne i oderwane od kontekstu jakiegokolwiek zewnętrznego sąsiedztwa.

Na koniec rozważań podstawiających powieści Zajdla do definicji totalitaryzmu warto wspomnieć wytłumaczenie syndromu państwa totalitarnego Zbigniewa Brzezińskiego i Carla Friedricha:

Syndrom, czyli zespół powiązanych cech dyktatur totalitarnych, składa się z ideologii, jednej partii kierowanej na ogół przez jednostkę, terrorystycznej policji, monopolu komunikacji, monopolu broni i centralnie kierowanej gospodarki ${ }^{20}$,

która w swej szerszej formie wskazuje sześć elementów niezbędnych do uznania państwa za totalitarne: oficjalna ideologia obejmująca wszystkie aspekty życia ludzkiego; jedna masowa, hierarchicznie zbudowana partia, całkowicie spleciona z biurokracją rządową; system terroru, który nie tylko wspiera, lecz także kontroluje przywódców partii; kompletny monopol środków przekazu i komunikacji społecznej; zupełny monopol środków przemocy i przymusu; centralna kontrola nad gospodarką ${ }^{21}$. Poza elementami widocznymi w powieściach cechami niezbędnymi dla Brzezińskiego i Friedricha, by nazwać system władzy totalitarnym, są masowa hierarchiczna partia polityczna oraz posługiwanie się oficjalną ideologią. Takie warunki może spełniać jedynie Paradyzja jako karykatura zamkniętego społeczeństwa opartego na kłamstwie, jednak żaden z pozostałych światów Zajdla nie wpisuje się w definicję syndromu państwa totalitarnego.

Kończąc rozważania na temat powodów, dla których nie uznaję twórczości Zajdla za opisującą totalitaryzm, jako swoje główny argument muszę wspomnieć wyjaśnienie totalitaryzmu autorstwa Hanny Świdy-Ziemby, które powstało jako głos odrębny w debacie o totalitaryzmie PRL. Jej definicja została zaprojektowana w taki sposób, by wykazać, dlaczego autorka uznaje PRL za państwo totalitarne i kładzie nacisk na inne elementy niż wszystkie do tej pory przeze mnie przywołane.

${ }_{19}$ H. Arendt, Korzenie totalitaryzmu, t. 1, przeł. M. Szawiel, D. Grinberg, Warszawa 1993, s. 494.

20 Z. Brzeziński, C. Friedrich, Dyktatura totalitarna, [w:] Władza i polityka. Wybór tekstów ze wspótczesnej politologii zachodniej, red. M. Ankwicz, Warszawa 1986, s. 210.

21 Z. Brzeziński, C. Friedrich, Totalitarian Dictatorship and Autocracy, New York-Washington-London 1965, s. 22. 
Totalitaryzm: System, w którym rządzący — stanowiący wyłączny, niekontrolowany ośrodek dyspozycyjny - stoją na straży jednolitych reguł obejmujących całokształt życia społecznego, reguł podtrzymywanych siłą przez aparat przemocy. [...] Z tego punktu widzenia całokształt życia ludzi zostaje ściśle zaprogramowany według jednego scenariusza. Jeśli scenariusz w jakimś zakresie się zmienia — zmiana ma charakter dyrektywny i obejmuje bądź całość systemu społecznego, bądź co najmniej całość określonej dziedziny, której zmiany dotyczą. W tej sytuacji aparat rządzący posiada szeroko rozbudowany aparat kontroli i infiltracji każdej dziedziny życia i wszystkich ludzi. Jest on bowiem nastawiony na szybkie reagowanie, gdyby ktokolwiek od obowiązującego scenariusza próbował się odchylić 22 .

Przy tak sformułowanej definicji totalitaryzmu, w której nacisk położony jest na scenariuszowość życia i kontroli państwa nad jego formą, rzeczywiście możemy uznać powieści Zajdla za mające w swym centrum totalitaryzm. Jest to jednak definicja bardzo specyficzna, stworzona do wyjątkowego ujęcia socjologicznego, którym autorka posługuje się w analizie wpływu PRL na polskie społeczeństwo. Znajduje się $\mathrm{w}$ związku z tym poza głównym nurtem definiowania systemu totalitarnego i jako ramy interpretacyjne dla twórczości Zajdla w mojej opinii musi ustąpić podejściu funkcjonalistycznemu, które moim zdaniem w sposób znacznie skuteczniejszy pokazuje intencje i cele autora.

Najbardziej charakterystyczna dla Zajdla jest perspektywa opisu rzeczywistości. Wszystkie społeczeństwa, które konstruuje w swych książkach, są ostro wydzielonymi fragmentami większej rzeczywistości. Zajdel przyjmuje jako aksjomat (w Limes inferior wyraża to explicite) założenia zbliżone do Parsonsowskiej teorii systemów społecznych. Systemy Zajdla są zamkniętymi, samoreferencyjnymi, samoodtwarzającymi się i samowystarczalnymi tworami, otoczonymi w szerszej perspektywie społecznej (która jest przez Zajdla pomijana; por. Limes inferior, Wyjście z cienia) przez identyczne sąsiednie systemy społeczne, które w zasadzie nie wchodzą z sobą w interakcje na codziennym, ogólnoludzkim poziomie. Nie tylko nie występuje tu przepływ jednostek pomiędzy sąsiednimi systemami, lecz jest on wręcz bezsensowny i bezcelowy. Wszystkie są w domyśle takie same. Dla treści książek i przemyśleń o społecznym zabarwieniu przepływy jednostek są nieistotne (Limes inferior, Wyjście z cienia) bądź ich obecność jest jedynie instrumentalnie wykorzystywana jako katalizator lęków społecznych przez aparat propagandy (Paradyzja, Cyliner van Troffa).

Na podstawie zaprezentowanych rozważań postaram się wyjaśnić, co uważam za prawdziwą podstawę twórczości Zajdla oraz główny temat jego książek. Jak wyłożyłem na początku artykułu, nie zgadzam się z określaniem jego literatury jako skupionej na totalitaryzmie twórczości opozycyjnej wobec PRL. Uznaję jego książki za przykłady znacznie szerszej próby spekulatywnego przedstawienia potencjalnych społeczeństw przyszłości, plasujące utwory Zajdla raczej w nurcie utopijnym niż antytotalitarnym. Spinającą jego wszystkie dzieła wspólną nicią jest wizja funkcjonowania systemu społecznego (a przez to politycznego,

22 H. Świda-Ziemba, Człowiek wewnętrznie zniewolony, Warszawa 1997, s. 57. 
ekonomicznego i socjalizacyjnego), ugruntowana w ramach strukturalnego funkcjonalizmu. Z dwóch najważniejszych teorii systemowych Talcotta Parsonsa oraz Niklasa Luhmanna jako ramy interpretacyjne wybieram teorię strukturalizmu funkcjonalistycznego Parsonsa, z uwagi na zbieżności jej elementów i ich opisu z tym, jak sam Zajdel opisywał Argonland w Limes inferior.

Parsons mówi, że

Społeczeństwa globalne mają tendencję do różnicowania się na podsystemy (struktury społeczne) wyspecjalizowane w każdej z czterech podstawowych funkcji. Tam gdzie zidentyfikowanie konkretnych struktur jest niemożliwe, jak to się często zdarza, można jednak częstokroć wyodrębnić typy tak wyspecjalizowanych ${ }^{23}$.

Każdy system społeczny w dążeniu do utrzymania równowagi musi rozwiązać cztery podstawowe problemy: musi być zdolny do przystosowywania się, osiągania celów, integracji oraz do kultywowania wzorów i usuwania napięć. Te elementy kluczowe funkcjonowania Parsonsowskiej wizji systemu społecznego odpowiadają czterem podsystemom obecnym wewnątrz struktury każdego systemu społecznego. Te podsystemy to:

— ad a pta cyjny — odpowiadający ekonomice i wytwarzający bogactwo rozumiane jako ,zgeneralizowane ułatwienia, jako środki o nieokreślonej liczbie zastosowań" $^{24}$;

— organizacyjny — odpowiadający polityce rozumianej jako osiąganie celów, który wytwarza mobilizacja warunków koniecznych do osiągania danych celów społeczeństwa jako systemu (bogactwo wytwarzane przez system adaptacyjny jest jednym z owych warunków), a więc ,maksymalizacja zdolności społeczeństwa do osiągnięcia jego celów systemowych" ${ }^{25}$, co Parsons nazywa władzą;

— integracyjny — ,wiąże kulturowe wzory wartości ze strukturami motywacyjnymi poszczególnych aktorów tak, by szerszy system społeczny mógł funkcjonować w sposób skoordynowany i bez zbytnich konfliktów wewnętrznych". Produktem takiego systemu jest zdolność kontrolowania zachowań, określana jako solidarność, rozumiana jako ,zgeneralizowana zdolność trzymania w ryzach jednostek systemu zgodnie z jego potrzebami integracyjnymi" 26;

- kultywowanie wzorów i usuwanie napięć „, koncentruje się na zinstytucjonalizowanej kulturze, która z kolei koncentruje się wokół wzorów orientacji na wartości. [...] Są one niemal stałe dla każdego systemu i względnie niezależne od ingerencji potrzeb związanych z celami bezpośrednimi

23 T. Parsons, N. Smelser, Funkcjonalne zróżnicowanie społeczeństwa, przeł. A. Bentkowska, [w:] Elementy teorii socjologicznych, wyb. W. Derczyński, A. Jasińska-Kania, J. Szacki, red. W. Derczyński, A. Jasińska-Kania, Warszawa 1975, s. 219-220.

${ }^{24}$ Ibidem, s. 220.

25 Ibidem, s. 221.

26 Ibidem, s. 223. 
i imperatywami adaptacyjnymi i integracyjnymi, jakim podlega system"27. System kultywowania wzorów i usuwania napięć koncentruje się na jednostce systemu, a nie całym systemie — „integracja jest kwestią stosunków pomiędzy jednostkami, kultywowanie wzorów zaś - kwestią stanów i procesów wewnątrz jednostek". Produktem tego podsystemu, czyli wkładem o zgeneralizowanym znaczeniu dla globalnego systemu społecznego, jest szacunek, a kiedy szacunek jest porównywany pomiędzy jednostkami, Parsons określa go jako prestiż. Prestiż jest więc ,zdolnością do działania w taki sposób, by czynić zadość wymaganiom danego systemu zinstytucjonalizowania wartości" 28

Przyjrzyjmy się teraz elementom strukturalizmu funkcjonalnego w twórczości Zajdla.

Systemy społeczne Zajdla są w rzeczywistości przemyślanymi i nastawionymi na kontrolę i zaspokajającymi wszystkie potrzeby więzieniami, których strażnicy obserwują funkcjonowanie systemu z zewnątrz $\mathrm{i}$ ingerują $\mathrm{w}$ wewnętrzne przepływy systemu jedynie w sytuacji ich niewydolności funkcjonalnej. Taki zamknięty i zaprojektowany system społeczny nie powinien potrzebować jakiejkolwiek ingerencji twórcy do codziennego bezbłędnego funkcjonowania. Wszystkie funkcje systemu działają samodzielnie w zamkniętych ramach. Jednak system nie pozostawia jednostek bez nadzoru. Kolorowe punkty będące walutą w Limes inferior, mierzony cyfrowo poziom człowieczeństwa, będący bazą dostępu do usług dostarczanych przez społeczeństwo, oparty na ciągłej inwigilacji system Paradyzji czy system uprawnień potwierdzających prawomyślność i bazujący na donosicielstwie miasta księżycowego Cylindra van Troffa są wewnętrznymi regulatorami zachowań jednostki opartymi na ciągłej inwigilacji i kontroli. W wypadku Limes inferior i Para$d y z j i$ są to systemy pozbawione czynnika ludzkiego, teoretycznie w stu procentach obiektywne. W rzeczywistości odgrywają one rolę adaptacyjną. Nie są systemami sprawowania władzy, lecz właśnie umożliwiającymi wiele zastosowań ułatwieniami. W przypadku kolorowych punktów Limes inferior, które znajdują się o poziom niżej w strukturze organizacyjnej, prawdziwym bogactwem jest mierzalny poziom inteligencji, który stanowi o pozycji jednostek.

Kolejną cechą łączącą światy Zajdla jest ich przemyślana i zaplanowana konstrukcja. Są to sztucznie stworzone systemy, oderwane od korzeni i historii oraz oparte na funkcjonalistycznym projekcie. Społeczności objęte planem budowy nowego społeczeństwa dążą $\mathrm{w}$ teorii do doskonałego zaspokojenia potrzeb społecznych oraz promowania rozwoju i szczęścia osobistego. Wszystkie elementy systemu społecznego, który je kształtuje i jednocześnie nimi zarządza niczym komputerowy system operacyjny, zostały przemyślane i zaplanowane, ale o ich prawdziwym znaczeniu mówi rzeczywista funkcja społeczno-ekonomiczna, a nie jej zewnętrzne pozory lub nazwa. Najbardziej jest to widoczne w Limes inferior,

27 Ibidem, s. 223.

28 Ibidem. 
w którym cały skomplikowany system przestępczości pełni w rzeczywistości funkcję wentyla społecznego i umożliwia zaspokojenie, teoretycznie niemieszczących się w granicach systemu, potrzeb i aspiracji ludności. Nawet najbardziej, wydawałoby się, szkodliwy dla systemu obiektywnych ocen kompetencji ludności proceder liftingu i downingu służy do sztucznego podwyższania lub zaniżania rzeczywistej klasy intelektualnej29. W zautomatyzowanym społeczeństwie Argolandu ${ }^{30}$ istnieje tylko zapotrzebowanie na pracę osób o wysokiej inteligencji, zdolnych do prac koncepcyjnych i kontrolnych. W związku z ograniczoną liczbą takich osób mają one obowiązek świadczenia pracy. Dlatego realna władza, widziana jako produkt systemu organizacyjnego, znajduje się nie w gestii ukrytej administracji Argolandu ani nawet nie w gestii nadzerowców (tajemniczych strażników systemu), lecz lifterów, takich jak Sneer, którzy mają realny wpływ na dystrybucję bogactwa oraz prestiżu.

Nie istnieją tam formalnie wentyle bezpieczeństwa dopuszczające do środków i dóbr luksusowych jednostki o niedostatecznej inteligencji, jednak mających inne predyspozycje i potrzeby zwykle związane ze sprawowaniem władzy. Procedura liftingu — sztucznego zawyżania klasy intelektualnej przez wysoce wyspecjalizowanego pracownika zwanego lifterem - stanowi wentyl bezpieczeństwa dla tych nieprzystosowanych do swej pozycji społecznej lub po prostu jednostek pragnących wykonywać jakąs pracę. Analogicznie usługa downingu pozwala jednostkom inteligentnym, jednak nieodczuwającym potrzeby służenia społeczeństwu pracą na prowadzenie nieskomplikowanego życia na utrzymaniu państwa. Lifterzy i downerzy, wraz z cinkciarzami, wampirami, zdziercami oraz wieloma innymi jednostkami, odgrywają wysoce wyspecjalizowane role spoza oficjalnych ram systemu, ale będące składnikami jego funkcji integracyjnej. Ma ona umożliwić skuteczne funkcjonowanie jednostkom pozbawionym dostępu do otaczającej je, i z pozoru zamkniętej na modyfikacje, struktury społecznej, łącząc wzory wartości ze strukturami motywacyjnymi, umożliwiając systemowi działanie bez poważnych konfliktów mogących wystąpić w sytuacji niedopasowania motywacji jednostek zdolnych, lecz niewystarczająco inteligentnych do własnej pozycji w ramach systemu.

Pomimo deklarowanych cech i zasad system społeczny Argolandu nagradza nie jednostki inteligentne, tylko lepiej przystosowane. Ponownie w rzeczywistości

29 Będącej podstawą przydziału do pracy oraz wynagradzania, przy czym niektóre dobra wytwarzane przez społeczeństwo są dostępne jedynie pracującym. System finansowy opiera się na trzech rodzajach punktów: dostępnych wszystkim i pełniących funkcje minimalnego dochodu gwarantowanego punktach zielonych, za które można kupić podstawowe, niezbędne do podtrzymania życia produktu; przydzielanych w dużo mniejszej liczbie punktach czerwonych, pozwalających na zakup używek i towarów z wyższej półki; oraz dostępnych tylko osobom pracującym punktach żółtych, które są jedynym sposobem do nabycia dóbr luksusowych i prestiżowych. Osoby o odpowiedniej do pracy inteligencji mają obowiązek jej świadczenia, natomiast osoby nieodznaczające się odpowiednim, potwierdzonym egzaminem, poziomem IQ nie mają możliwości pracy.

30 Argoland to miasto-system w Limes Inferior. 
w systemach samozarządzających się, jakim są systemy Parsonsa i Zajdla, prestiż i szacunek nie zależą od rzeczywistej pozycji jednostki, lecz od posiadanego statusu, wyznaczanego liczbą punktów. Główny bohater Limes inferior, pomimo przypisania do najwyższej klasy społecznej (mierzonej, przypominam, poziomem inteligencji), wybiera życie osoby głupszej, ale utrzymywanej oficjalnie przez państwo (praca jest obowiązkowa wyłącznie dla osób spełniających kryteria). Wysoki standard życia i dostęp do bogactw systemu gwarantuje mu dochód zdobywany nielegalną działalnością. Jego szacunek nie bierze się z oficjalnie głoszonej ideologii systemu ani jego powierzchownych zasad, lecz z wytworzonych przez samego siebie ram, w które zamyka swoje życie. Wobec możliwość zostania „nadzerowcem” — jednym z tajemniczych architektów i programistów systemu - okazuje się, że zamknięta konstrukcja ram społecznych była dla niego po prostu niewystarczająca, a po jej rozszerzeniu wreszcie zdobywa możliwość oraz punkty odniesienia umożliwiające przekształcenie szacunku w prestiż.

Owa ukazana tu głównie na przykładzie Limes inferior funkcjonalistyczna, strukturalistyczna, systemowa rama jest wspólna dla wszystkich powieści Zajdla. W rzeczywistości można je potraktować jako intelektualne ćwiczenie polegające na wstawianiu w zaplanowany i wyraźnie określony schemat sztucznie konstruowanych społeczeństw znajdujących się w całkowicie odmiennych warunkach wstępnych. Jest to ciekawe, zwłaszcza gdy weźmie się pod uwagę, że każdy $\mathrm{z}$ jego światów jest kompletnie odmienną rzeczywistością, a jedynymi wspólnymi dla nich elementami są pewne specyficzne, czytelne dla mieszkańca ówczesnej Polski, a często trudne do rozszyfrowania dzisiaj, kody kulturowe.

W przeciwieństwie do funkcjonalistycznych ram cechy systemów totalitarnych, które dają się rozpoznawać w poszczególnych rzeczywistościach Zajdla, nie są tak jednorodne. Zostają przypisane każdorazowemu układowi świata i przynależą do relacji władzy w konkretnym społeczeństwie. Imperatywy funkcjonalistyczne są jednak widoczne w każdym z jego światów. Podobieństwa między powieściami Zajdla wynikają właśnie z powtarzalności warunków brzegowych, w których powstawały, a nie z opisywania jednego ustroju jako punktu odniesienia.

Unikalna mieszanka stworzona przez specyficzne parsonsowskie podejście do rzeczywistości w połączeniu z siłą i barwą wizji zapewniły dziełom omawianego autora żywotność większą, niż wynikałaby z dysydenckich założeń przemycania literatury politycznej pod płaszczykiem fantastyki. Kultowość jego książek w pokoleniu lat siedemdziesiątych zaowocowała zadedykowaniem Zajdlowi po jego przedwczesnej śmierci w 1985 roku nagrody Fandomu Polskiego dla najlepszych utworów fantastycznych. O ich sile świadczy również to, że wciąż są żywe, wydawane w wysokich nakładach i ciągle się sprzedają. Dzięki umiejętnemu połączeniu fabuły z uniwersalną refleksją na temat wolności i charakteru jednostki zapewniły powieściom Zajdla ważne miejsce w literaturze fantastycznej końca XX wieku. Co jednak zaskakuje, to to, że mimo dawnego odejścia rzeczywistości 
PRL i całkowitej zmiany warunków, w których żyjemy, wciąż mogą być podstawą bardzo ciekawej analizy funkcjonowania społeczeństwa i specyficznych zasad i praw, według których ono działa.

\section{Bibliografia}

Arendt H., Korzenie totalitaryzmu, t. 1, przeł. M. Szawiel, D. Grinberg, Warszawa 1993.

Brzeziński Z., Friedrich C., Dyktatura totalitarna, [w:] Władza i polityka. Wybór tekstów ze wspótczesnej politologii zachodniej, red. M. Ankwicz, Warszawa 1986.

Brzeziński Z., Friedrich C., Totalitarian Dictatorship and Autocracy, New York-Washington-London 1965.

Chojnicka K., Olszewski H., Historia doktryn politycznych i prawnych, Poznań 2004.

Kurczewski J., Dawny ustrój i rewolucja, [w:] Konflikt i solidarność, Warszawa 1981.

Parowski M., Z pozycji małego brata, „Nowa Fantastyka” 1990, nr 2.

Parsons T., Smelser N., Funkcjonalne zróżnicowanie społeczeństwa, przeł. A. Bentkowska, [w:] Elementy teorii socjologicznych, wyb. W. Derczyński, A. Jasińska-Kania, J. Szacki, red. W. Derczyński, A. Jasińska-Kania, Warszawa 1975.

Podgórecki A., Kontrola społeczna trzeciego stopnia, [w:] Problemy profilaktyki społecznej i resocjalizacji, [red. H. Dziewanowska], Warszawa 1976.

Podlewski A., My z niego wszyscy? Fantastyka socjologiczna w roku zajdlowskim, „Teologia Polityczna" 2013, nr 2.

Świda-Ziemba H., Człowiek wewnętrznie zniewolony, Warszawa 1997.

Walicki A., Totalitaryzm i posttotalitaryzm. Próba definicji, [w:] Społeczeństwa posttotalitarne. Kierunki przemian, red. Z. Sadowski, Warszawa 1991.

Wnuk-Lipiński E., Science fiction jako opis socjologiczny, „Newsweek” 11.12.2004, http://www. newsweek.pl/science-fiction-jako-opis-socjologiczny,45744,1,1.html.

Zajdel J.A., Cała prawda o planecie Ksi, Warszawa 1983.

Zajdel J.A., Cylinder van Troffa, Warszawa 1980.

Zajdel J.A., Limes inferior, Warszawa 1982.

Zajdel J.A., Paradyzja, Warszawa 1984.

Zajdel J.A., Szkice niepublikowanych powieści „Enklawa” $i$, Residuum”, „Nowa Fantastyka” 1986, nr 2.

Zajdel J.A., Wyjście z cienia, Warszawa 1983.

\section{TOTALITARIAN REGIME AS A SYSTEM OF STRUCTURAL FUNCTIONALISM IN THE LITERATURE OF JANUSZ A. ZAJDEL}

\section{Summary}

In the Polish literature of the last two decades of the Polish People's Republic (PRL), science fiction, especially sociological science fiction, served as a substitute for political literature, which was impossible to publish under state censorship. The majority of this genre was anti-utopian or critical of the totalitarian reality. This attitude was hidden under fantastical make-up and was very strongly related to the here-and-now of the period in which the books originated. Janusz A. Zajdel is the most important representative of this genre, however, at the same time he manages to avoid limiting his work to the thinly veiled politics of the time. While the topics of his work very often repeated themselves the stories go beyond the drama of the individuals or groups confronted with 
the totalitarian regime and focus on certain repeatable mechanisms within the system itself. Due to the above characteristics, his literary work transcends from being just a criticism of the internal workings of PRL into the area of structural functionalism of a universal social system.

Social structures that play a central role in Zajdel's work, are always built from the same, very clearly outlined building blocks. It may seem that the characters and the plot of the novels are only an addition to the views on the structure and the shape of society expressed by the author. Common elements that build that world remain at the core of all the novels and the pretextual story lines of Zajdel make it easier to present those elements in the internal functioning of the sometimes very complicated social systems that Zajdel describes. Dysfunctional elements that prevent the exercise of totalitarian control inside the system, for Zajdel seem to be of far greater importance than his story lines.

These relations, so characteristic of the late PRL, referred to in the literature as "dirty togetherness", are phenomena of exercising control over specific measures and social resources available in the framework of the social system for the implementation of not the objectives, which were designated by those socio-political systems, but by social groups or entities that use them for their own purposes. The main theme of Zajdel's novels are dysfunctions that occur as part of the totalitarian system, but his social systems never meet the defining criteria of totalitarianism in the classic sense. Totalitarianism is not the main intrest of the novels but is only used instrumentally as the make-up for the description of the mechanism of the internal workings of these dysfunctions. Zajdel sees dirty togetherness as a structural element of the system, without which the continuous functioning of the system would be impossible.

Keywords: social system, totalitarian regime, functions, dirty togetherness.

Andrzej Wróbel

a.wrobel@uksw.edu.pl 